\title{
回 回
}

\section{翼列に関する2，3の問題}

河 崎 俊 夫*

ガス・タービンあるいは䊺空用ジェット・エンジン

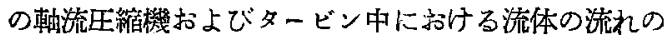
研究に関連して，最近翼列について多くの研究吕行わ れている。しかしながら問題を 2 次元的な翼列のみに 限っても，末充分に解明せらられていない分野分多い。 ここではそれらの問題の中から興味あると思われるも。 のを紹介したいと思 弓。

\section{§1. 国列に関する理論と実驗との比輐}

任意の翼型よりなる翼列を通って流れるポテンシャ ル流を解く問題は，既に多くの人々が各種の方法を用 いて解いている。方法的に分けると，

(a) 等角写像によるもの

(b) 一枚の翼について他の翼の影響を考えるもの

（c）流線を基準として求めるもの

等になる。

今これらの方法による理論と笑験とを比咬してみよ

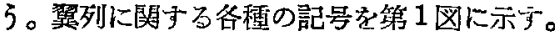
第 1 表は揚力保数 $C_{z}$ の比較を示す(1)。 $C_{z}$ は平均

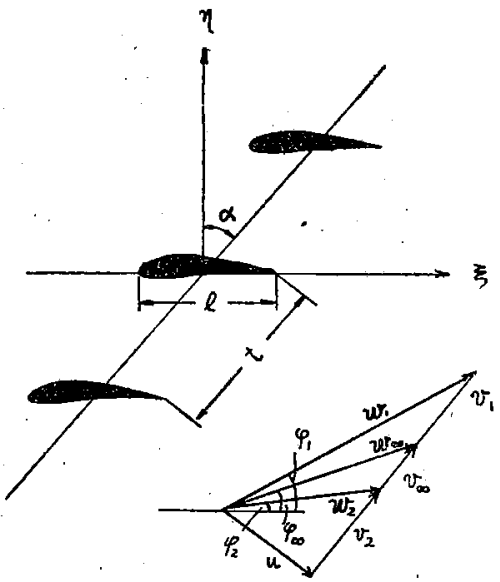

第 1 図 第 1 表

\begin{tabular}{|c|c|c|c|c|c|c|c|c|c|c|c|}
\hline & & 篹 & 型 & $t / l$ & $\alpha$ & $\varphi_{1}$ & $\varphi_{\infty}$ & $\varphi_{2}$ & $C_{z}$ 理論 & $\begin{array}{c}C_{z} \text { 压力 } \\
\text { 分布 }\end{array}$ & $C_{z}$ 流出角 \\
\hline 案 & 內 賈 & NACA & $65-810$ & 1.000 & $-8.6^{\circ}$ & $8.6^{\circ}$ & $1.8^{\circ}$ & $-4.8^{\circ}$ & 0.73 & 0.46 & 0.47 \\
\hline & 'n & " & $65-1210$ & " & $-14.2^{\circ}$ & $14.2^{\circ}$ & $3.4^{\circ}$ & $-6.6^{\circ}$ & 1.11 & 0.70 & 0.75 \\
\hline & 首機用垡 & & $65-410$ & " & $49.0^{\circ}$ & $11.0^{\circ}$ & $6.5^{\circ}$ & $0.7^{\circ}$ & 0.79 & 0.54 & 0.62 \\
\hline & " & " & $65-810$ & $"$ & $50.4^{\circ}$ & $9.6^{\circ}$ & $4: 4^{\circ}$ & $-2.5^{\circ}$ & 0.92 & 0.56 & 0.72 \\
\hline & $"$ & & $65-1210$ & " & $45.9^{\circ}$ & $14.1^{\circ}$ & $7.5^{\circ}$ & $-2.1^{\circ}$ & 1.47 & 0.63 & 0.92 \\
\hline & ビン用翼 & & $\ldots$ & 0.556 & $-29.7^{\circ}$ & $61.7^{\circ}$ & $10.2^{\circ}$ & $-23.4^{\circ}$ & 2.50 & 2.00 & 2.03 \\
\hline
\end{tabular}

速度 $w_{\infty}$ を基淮としたものであり，翼型のまわりの圧 力分布を積分して求めたものと，流出方向の測定値上 り阡算したものをを示してある。第 1 に揚力保数 $C_{z}$ の值は以上雨者々も理論值 ((b)の方法で計算された もの(9) 上りかなり小さい。この原因として大体 $2 つ$ のことが渃えられる。

(1) 後に§2 で述べるように, 翼列の流れには 2 次的流れが存在し，そのために翼の位置に迎角を少く する力向の誘導速度を生ずる。この誘導速度のために

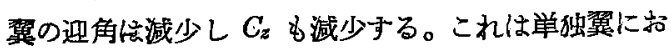
いて，絽横比の揚力に対する影響とよく似ている。し かしその修正量は通常あまり大きくなくこれれ゙゙けで
上記の理論と実験との差を說明することはできない。

（2）樊それ自身か境界層のために，理諭値に比べ て揚力傾科か減少しかつ零揚力角が移動する。とくに 第 1 表の NACA 65 系統の翼型は単独翼としても揚 力傾科の娍少はかなり著しい(1)。また零揚力有の移動 は単独翼ではあまり認められないが，翼列に扎いては 堌速翼列では理論值より負の迎角の方に減速翼列では 理㻅值上り正の迎角の方に移動する上うである( ${ }^{(3)}$ 。以

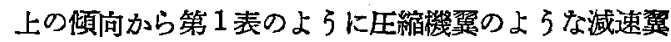
列の方が，タービン翼のような增速翼列よりも理論と の差が大きい。

第 2 には翼型等面の圧力分布より得られた $C_{z}$ の方 


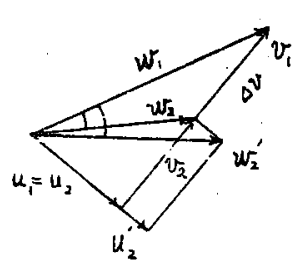

第 2 図
が，流出方向より得られ

た $C_{z}$ の值より小さいこ とである。これは第2図 のようにして定性的に說 明さ狆る。すなおち翼列 軸方向の速度昰化 $\Delta v$ は 同じとしこも，翼型の抵

抗 2 二的な流れによる損失扎よび側壁の摩擦損失など によって，後流に入らないところの出口軸流速度 $u_{2}^{\prime}$ は平均出口軸流速度 $u_{1}$ より大きい。第 2 図より転 向角 $w_{1}$ そ $w_{2}^{\prime}$ とのなす府は大きくなる。

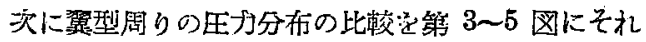
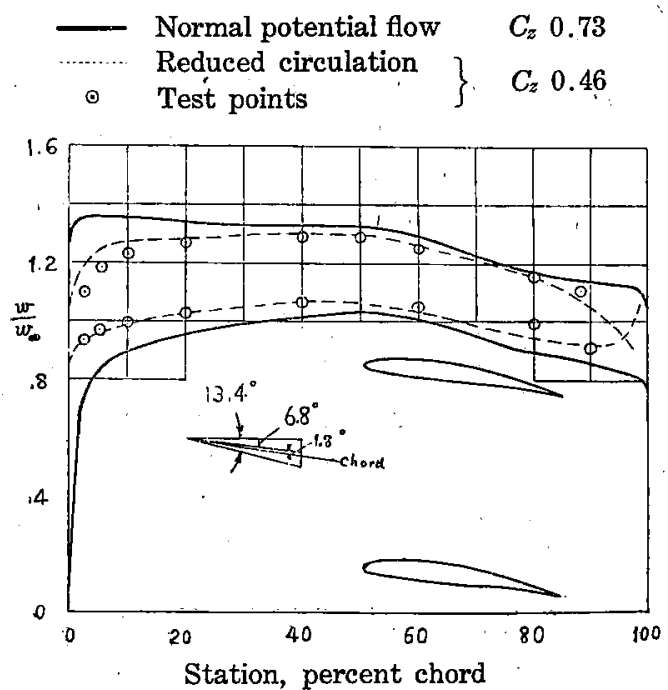

NACA $65-810 \quad a=-8.6^{\circ} \varphi_{\infty}=1.8^{\circ} \frac{t}{l}=1.00$
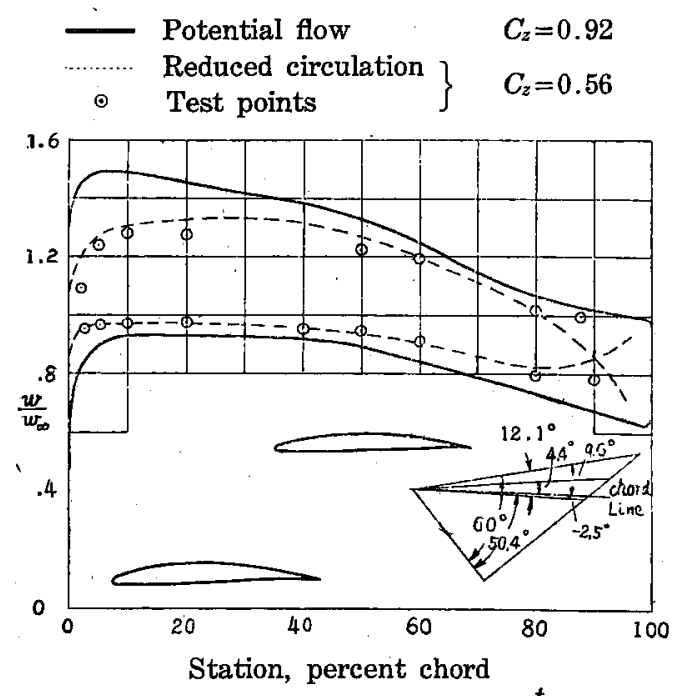

NACA $65-810 \quad \alpha=50.4^{\circ} \quad \varphi_{\infty}=4.4^{\circ} \quad \frac{t}{l}=1.00$

第 4 図

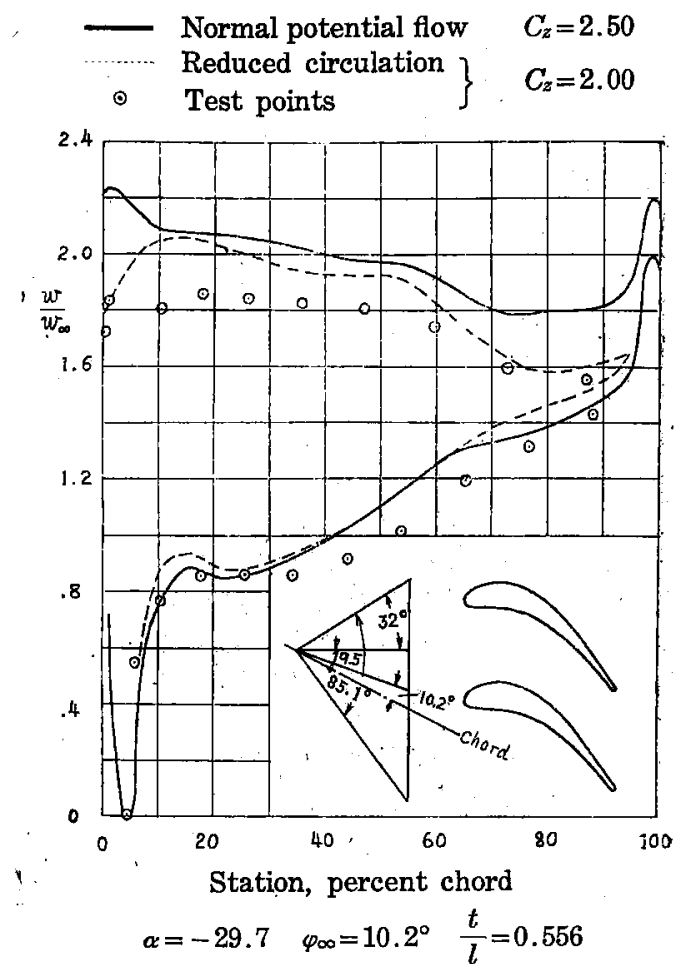

第 5 図

ぞれ入口案内翼・匡縮機用翼およびタービン翼のもの を示す(1)。図中奏線は理碖の与える $C_{z}$ の値のもので

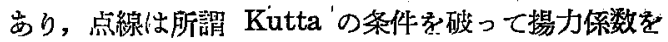
実験値と合わせたものである。大体の倾向は合ってい る。その他の資料によっても，入下案丙潩むるいは夕 ービン・ノズルに封しては第3图よりよい一敖が見

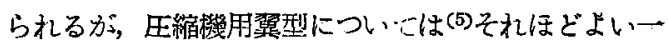
敨は得られてていない。

\section{§2. 損失}

翼列においては，翼型の形状抵抗のほかにも各種の 損失がある。その中でも最も大きなものは所謂 2 次的 な流れによる損失と，側壁の摩撜損失とである。

2 次的な流水による損失は(6)，垡型によって気流が

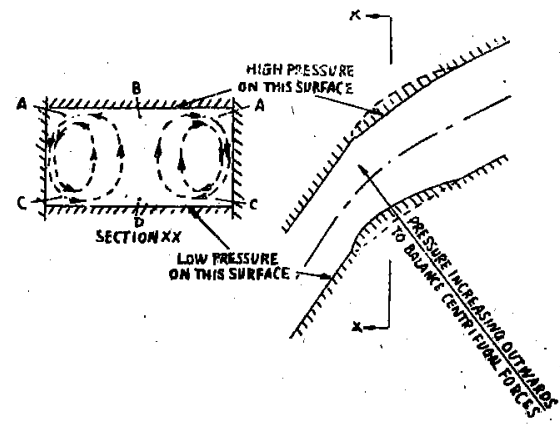

第 6 図 
曲げられるために生ずる ものである。今第6図の 上うに，翼列の 2 枚の路 を境とした 1 ピッチの間 の流九妾考光当。流線は 図のように曲げられるの で遠心力が洒く。この遠 心力は翼の上面の負圧と 下面の正の圧力とで釣合 っていなければならな いところか測壁の近く では粘性のために速さが 隇少するから，遠心力は 小さくなり，したがって それと釣合うべき圧力勾 配る小さくてすむわけで ある。すなわち A 点の 欧力は $B$ 点の珢力上り 低く, $\mathrm{C}$ 点の压力は $\mathrm{D}$ 点 の肚力上り高い。その結 果図に点線で示したよう
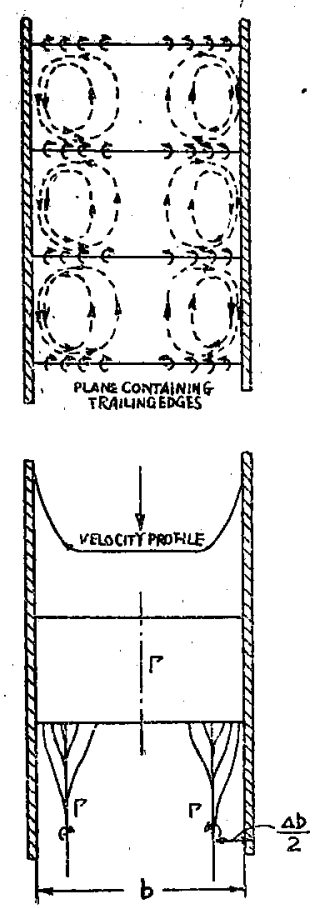

第 7 図
な2次的な流れが発生する。この現象は管の曲りにお ける 2 次的な流れとして古くより知られているが，翼 列においてを同じ現象があらわれるわけである。これ を翼理論の立場より見れば，翼は或る强さの偱環をむ っているが，壁の近くでは速さが減るので偱摆も減少 し，壁面では循環は零となる。䛻罢の減少した量は佩 系となって後方に流れ出る。しかし渦系は不安定であ って直ぐに一本の強い瀜線にまとまる。この渦線の強 さは翼の㯰罢 $\Gamma$ に等しい。瀜の中では運動エネルギ 一は回転速度の形で存在するけれども，この速度の成 分は後流の圧力上昇には寄与しないので損失々見なさ れる(第7図)。また第 7図より見られるよ弓に，2次 的流れは翼巾の中央部では転向角紊淢らすよ5\%方向 に向かい，端の方では增加する方向に向かっている。 これらのことは第 8 図の全王損失と転向角の測定結果 とによって亳付けられている。

これを解析的に取り扱うには上述した洞線によ゙る影

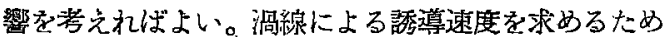
に，壁を鏡像点における渦で置きかえて第 9 図す上万 な瀜線の分布を考える。翼湢を $b$ とし渦線の位置を壁 から $4 b / 2$ とするを，翼の位置における誘導速度ば前 方無限遠より後方無限遠まで続く洞線によるものの牛 分だから，一組の瀜線によって翼の中央部に誘導され る速度の $w_{\infty}$ に垂值な成分 $\Delta w_{i}$ は

$$
\Delta w_{l}=-\frac{F}{2 \pi} \frac{\Delta b}{2} \frac{x^{2}-y^{2}}{x^{2}+y^{2}}
$$
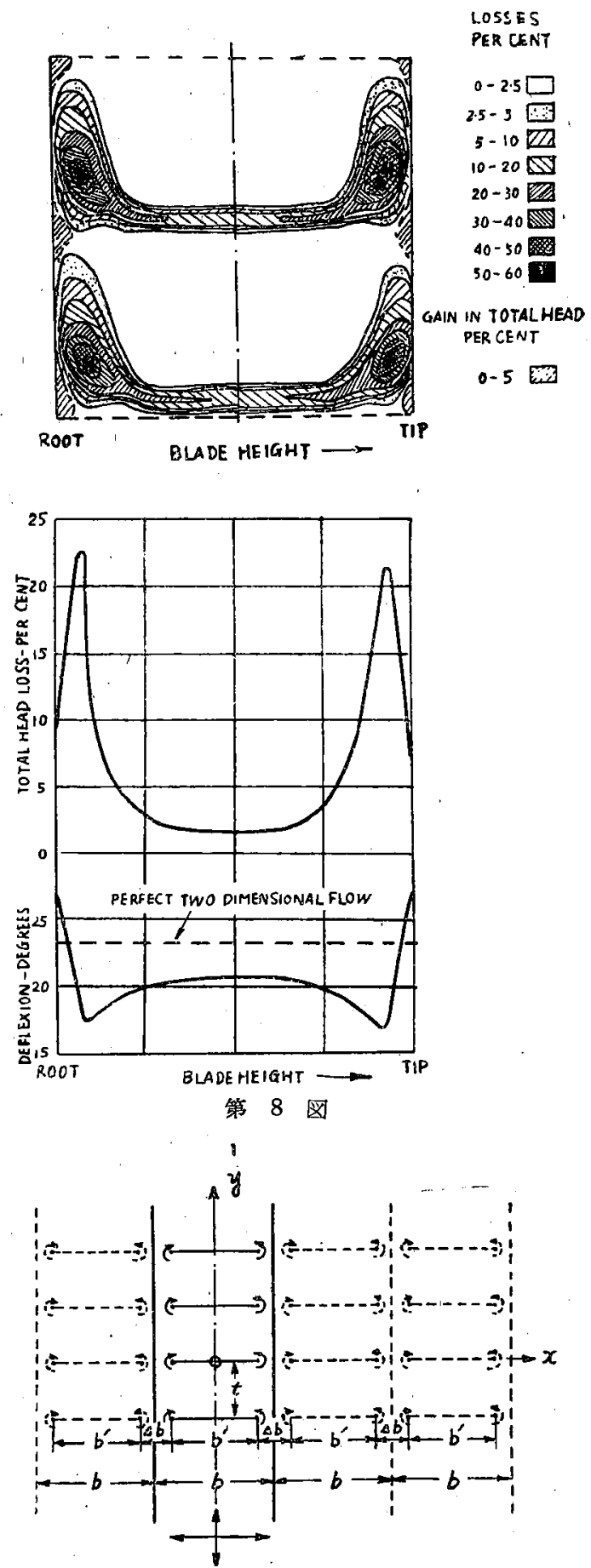

第 9 図

である。ただし $x, y$ は 1 組の洞線の位置の中点の 座標である。これを全部の瀜線についての和をとると

$$
w_{i}=\frac{\Gamma}{\pi} \frac{2 \Delta b}{2 b} \sum_{n=-\infty}^{n=+\infty} \sum_{m=1,3,5, \ldots} \frac{m^{2}-n^{2} 4 t^{2} / b^{2}}{\left(m^{2}+n^{2} 4 t^{2} / b^{2}\right)^{2}}
$$

$t / b$ が小さい時はこの和は $\pi b / 4 t$ となり,また循環 $\Gamma$ 
を $C_{z}$ で表わす

$$
\frac{\Gamma}{w_{\infty}}=\frac{l C_{z}}{2}
$$

の関係を用いると，誘導边危 $e$ は (1) 式より

$$
e \equiv \frac{w_{i}}{w_{\infty}}=\frac{1}{4} \frac{C_{z}}{t / l} \frac{\Delta b}{b}
$$

となりこれによる誘導抵抗 $C_{x i}$ は

$$
C_{x i}=\frac{1}{4} \frac{C_{z}^{2}}{t / l} \frac{\Delta b}{b}
$$

寸なわち完全に 2 次元の翼列に較べて迎危は $e$ だけ 增し，抵抗は $C_{x \varepsilon}$ †゙け增加したことになる。この関 係紧独翼における綎横比の影響と非常に上く似てい る。次に側壁の磨䏅抵抗による頙失は，平均速度 $w_{\infty}$ を基準にとった摩势抵抗を $C_{f}$ とすると

$$
C_{x z}=2 C_{f} \frac{t}{l} / \frac{b}{s}
$$

$s$ は第 11 図に示した軸方向に測？た翼型の受持つ長 さで岁る。抵抗係数 $C_{f}$ は增速翼列の場合子減速烈列 の望合さでは大いに異なるが，生縮機などでは大体 $C_{f}=0.010$ くらいにと就上い(7)。 今 $C_{f}=0.010$ と して $s \approx l$ とすると

$$
C_{:: \pi}=0.020 \mathrm{t} / \mathrm{b}
$$

全体の抵抗 $C_{x}$ は，浑型の形状担抗を $C_{x p}$ とする 飞

$$
C_{x}=C_{x p}+C_{x \ell}+C_{x a}
$$

\begin{tabular}{|c|c|c|c|}
\hline $\begin{array}{l}\text { ty profile.............. } \\
\text { asional loss, per cent. } \\
\text { per cent } \ldots \ldots \ldots \ldots \\
\text { loss, per cent } \ldots \ldots \ldots \\
\text { oss, per cent........ } \\
\text { ared) } \ldots \ldots \ldots \ldots \ldots \ldots \ldots\end{array}$ & $\begin{array}{l}4 \\
\mathrm{I} \\
3.9 \\
1.7 \\
0.4 \\
1.8 \\
0.08\end{array}$ & \begin{tabular}{|l|}
4 \\
II \\
4.9 \\
1.7 \\
0.4 \\
2.8 \\
0.16
\end{tabular} & \begin{tabular}{|l}
2 \\
III \\
5.4 \\
1.7 \\
0.8 \\
2.9 \\
0.16
\end{tabular} \\
\hline
\end{tabular}

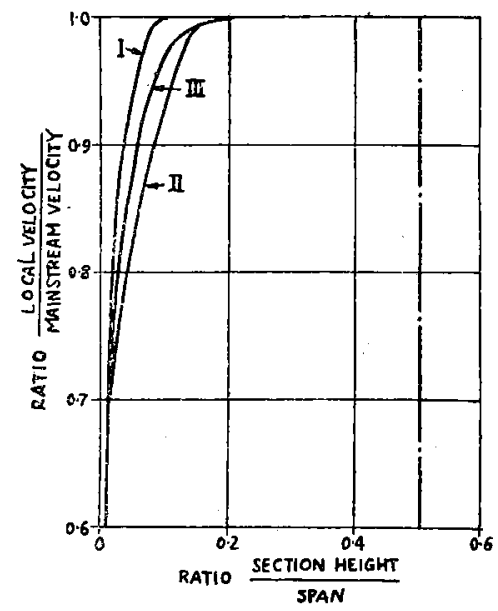

Aerofoil, 10 C 1/40 C 50. Stagger, $-27.5 \mathrm{deg}$. Pitch/chord, 0.94.

筑 10 図

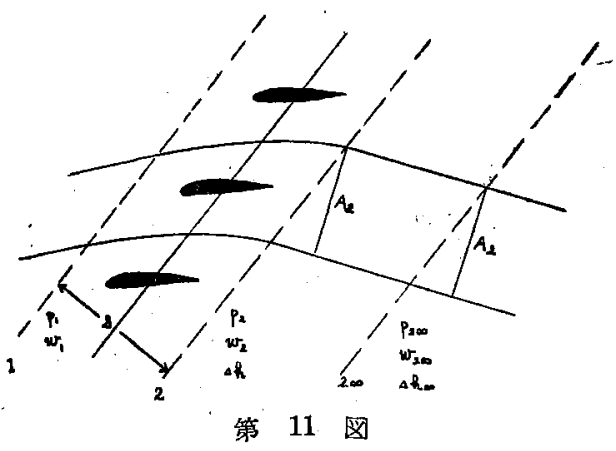

1 例老第 10 图に示す。この表では 2 次的揁失は， 全体の損失から形状抵抗と（6)式によって訐算した壁 の摩擦䭫失を引いて承めたものである。2 次的钼失は ほぼ測定した $\Delta b / b$ の值心比例している。またこの例

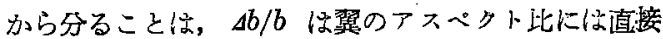
関係せず，むしろ潩列大口の速度分布と翼列を通して

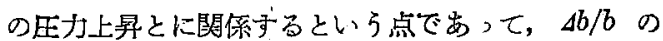
評価を著しく困踓にしている。現在のところで法直接 測定する以外によい方法はなさそうである。

\section{§3. 压力上昇}

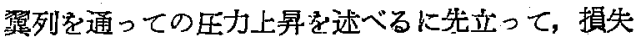
と质力上舁との関係を明らかにしておこう。第 11 図 の上らに調查面を翼列軸に平行に無限前方後方にとり

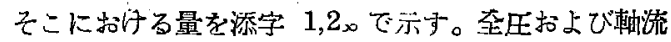
速度については，

$$
\begin{aligned}
& p_{1}+\frac{1}{2} \rho w_{1}^{2}=p_{2 \infty}+\frac{1}{2} \rho w_{2 \infty}{ }^{2}+\Delta h_{\infty} \\
& u_{1}=u_{5 \infty} \ldots \ldots \ldots \ldots \ldots \ldots \ldots \ldots
\end{aligned}
$$

ただし $p$ は静圧， $\Delta h_{\infty}$ は全压の唄失である。

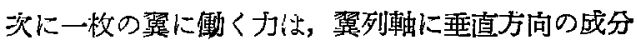
$X$, 本行の战分 $Y$ とすると, 翼列前後の運動量の变 化より

$$
\begin{aligned}
& X=\left(p_{1}-p_{2 \infty}\right) t \\
& Y=\rho\left(v_{1}-v_{2}\right) u_{1} t
\end{aligned}
$$

(1)，(2) 式を用いると（3）式は

$$
X=-\rho\left(v_{1}-v_{2 \infty}\right) v_{\infty} t+\Delta h_{\infty} t
$$

ただし $v_{\infty}$ は $v_{1}$ と $v_{3 \infty \infty}$ との平玸値である。

今翼型に働く揚力・抗力を平海速度 $w_{\infty}$ の方向に 垂直怙よび本行な力の或分と定域すると

$$
\begin{aligned}
& L=Y \sin \beta_{\infty}-X \cos \beta_{\infty} \\
& D=Y \cos \beta_{\infty}+X \sin \beta_{\infty}
\end{aligned}
$$

(4)，(5) 式を用いて

$$
\begin{aligned}
& \dot{L}=\rho\left(v_{1}-v_{2 \infty}\right) w_{\infty} t-\Delta h_{\infty} t \cos \beta_{\infty} \\
& D=\Delta h_{\infty} t \sin \beta_{\infty} \ldots \ldots \ldots \ldots \ldots .
\end{aligned}
$$

すなわち同じ出口す问で流出する（同じ $Y$ の值をる つ）損失なしの流れの暢合に比較して，揚少は減少し 
抗力が生じたと考えてよい。保数の形にすると

$$
\begin{aligned}
& C_{z}=\frac{L}{\frac{1}{2} \rho w_{\infty}^{2} l}=2 \frac{t}{l}\left(\cot \beta_{1}-\cot \beta_{2}\right) \sin \beta_{\infty} \\
&-\frac{\Delta h_{\infty}}{\frac{1}{2} \rho w_{\infty}^{2}} \frac{t}{l} \cos \beta_{\infty} \ldots \ldots \ldots \\
& C_{x}=\frac{D}{\frac{1}{2} \rho w_{\infty}^{2} l}=\frac{\Delta h_{\infty}}{\frac{1}{2} \rho w_{\infty}^{2}} \frac{t}{l} \sin \beta_{\infty} \ldots \ldots \cdots
\end{aligned}
$$

また压力上我は (1)，(2) 式より

$$
\begin{aligned}
\frac{p_{2 \infty}-p_{1}}{\frac{1}{2} \rho w_{1}^{2}} & =1-\left(\frac{w w_{3 \infty}}{w_{1}}\right)^{2}-\frac{\Delta h_{\infty}}{\frac{1}{2} \rho w_{+}^{2}} \\
& =1-\left(\frac{\sin \beta_{1}}{\sin \beta_{2}}\right)^{2}-\frac{\Delta h_{\infty}}{\frac{1}{2} \rho w_{1}^{2}}
\end{aligned}
$$

以上は翼列より充分後方で流れが一様になった所の 調査面で測定した量より，揚力抗力を算出する式であ るが，実際にはもっと翼列に近い調盗面で測定するこ と多多い。その場合には第 11 四のように考之る。翼 列に比咬的近い調査面 2 を考え，そこでは静圧和よび 方向は一定であって，それが泊合によって無限後方の 状態に達すると考える。全王は

$$
\begin{aligned}
p_{1}+\frac{1}{2} \rho w_{1}^{2} & =p_{2}+\frac{1}{2} \rho v_{2}^{2}+\Delta h=p_{2}+\frac{1}{2} \rho w_{2}^{* 2} \\
& =p_{200}+\frac{1}{2} \rho w_{200}{ }^{2}+\Delta h_{\infty}
\end{aligned}
$$

ただし $\Delta h$ は全生の損失であって， $w_{2}$ と共に流線に よって異なる。 $w_{3}^{*}$ は全压損失のない点における流出 速度である。次に連続の式は

$$
w_{200} A_{2}=\int w_{2} d A_{2} \cdot
$$

$A_{2}$ は第 11 図に示したように後方において一枚の算 が受持つ流体部分の断面䅡である。

さらに流出方向についての運動量の保存を考えると

$$
p_{2 \infty} A_{2}+\rho w_{200} A_{2}=p_{2} A_{2}+\int \rho w_{2}^{2} d A_{2}
$$

(11)，(13) 式より

$p_{2 \infty}+2 \Delta h_{\infty}=p_{2}+2 \int \Delta h \frac{d A_{2}}{A_{2}}$

一方 (11) 式上り

$$
p_{2 \infty}-p_{2}=\frac{1}{2} \rho 2 v_{2}^{* 2}\left(1-\left(\frac{w_{2 \infty}}{w_{2}^{*}}\right)^{2}\right)-\Delta h_{\infty}
$$

この両式より $\left(p_{2 \infty}-p_{3}\right)$ を消去して

$$
\Delta h_{\infty}=2 \int \Delta h \frac{d A_{2}}{A_{2}}-\frac{1}{2} \rho w_{2}^{* 2}\left(1-\left(\frac{w_{2 \infty}}{w_{2}^{*}}\right)^{2}\right) \text {. }
$$

$w_{2 \infty} / w_{2}^{*}$ は (12) 式から

$$
\frac{w_{2 \infty}}{w_{2}^{*}}=\int \frac{w_{3}}{w_{2}^{*}}: \frac{d A_{2}}{A_{2}}
$$

以上で $\Delta h_{\infty}$ と $w_{2 \infty}$ を求めたが，殴力上昇の損失
は $\Delta h_{\infty}$ と $\left(p_{2 \infty \infty}-p_{2}\right)$ との和でめって

$$
\Delta h_{\infty}+\left(p_{2 \infty}-p_{3}\right)=\frac{1}{2} \cdots{ }_{2}^{* 2}\left(1-\left(\frac{w_{2 \infty}}{w_{2}^{*}}\right)^{2}\right) \cdots
$$

（14）（16）式注 2 次的損失や側壁の摩撚損失のある 場合にもそのま利用できる。( $\left(p_{200}-p_{2}\right)$ は NACA における一奉験で指据されているよ弓に後流において 回収される可能性はあるが一応損失と見なされねばな らない。

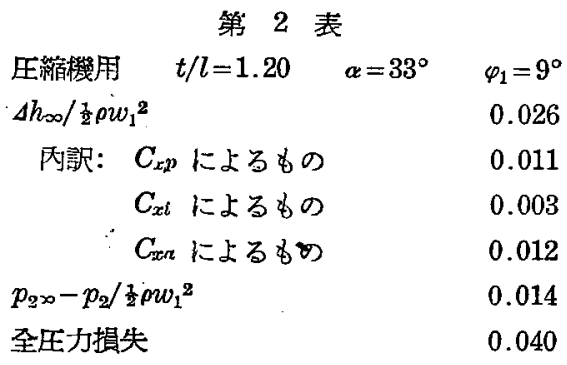

筆者の所で行った 1 例を示そう。(第 2 表)これい: 約 $1 / 3$ 弦長後流で断面全体について測定を行 たもの である力゙，そこでは $p_{x \infty}-p_{2}$ は全体の正力損失に対 して相当の割合を占めている。なおここの例で側壁の 摩摖抵抗が大きな割合を占めているのは前方の調查面 がかなり翼列の前方にあるためで通常はこの値の半分 くらいと思われる。2 次的流狆の 損失が小さいのは $C_{z}=0.570$ 程度であ密り大きくないのと，前方の境界 層厚さがかなり小さいので $\Delta b / b$ が小さいためであろ 万。またこの例で䖽型表面の王力行布より求めた損失 のない場合の压力上氭は $\Delta p / \frac{1}{2} m w_{1}^{2}=0.243$ でこれか ら上記の損失を差引くと 0.203 になる。これに对す る実験値は 0.193 であって，この程度の差は実験誤差 そ考えられる。第 2 尝の数值にも相当の測定誤差が入 ってくるが大体の傾向としては正しいものと思われ る。

この混合か浣全でないための損失は，翼列の或る程 度後方でば回復されるが，実際の圧繀機等の設計にお いて動翼と静翼との間隔を充分にとることは困難であ 万う。

結語 翼列に関する各種の問題の中から，翼列理論

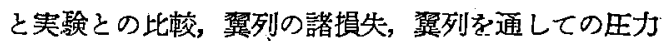
上戒について述べたが，筆者の猸い見地から思わざる 誤りを犯すことを恐れるものである。

*邀转技術研筷所

(1) S. Katzoff, H.E. Bogdonoff \& H. Boyet: Comparisons of Theoretical and Experimental Lift and Pressure Distributions on Airfoils in Cascade NACA Note 1376 (1947)

(2) S. Katzoff, R.S. Finn \& J.C. Laurence: Interference Method for Obtaining the Potential Flow Past an Arbitrary Cascade of Airfoils NACA Note 1252 (1947)

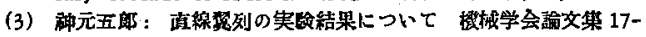
58 (1951) 
(4) M.C. Huppert \& C. MaeGregor : Comparisons between Predicted and Observed Performance of Gas-Turbine Stator Blade Designed for Free-Vortex Flow NACA Note 1810 (1949)

S. Uchida: Calculation of Compressible Cascade Flow by the Method of Flux Analysis (1952)

(5) J. R. Weske: An Investigation of the Aerodynamic Characteristics of a Rotating Axial-Flow Blade Grid. NACA Note 1128 (1947)

M. Charcosset: Méthode Hodographique de Tracé des Profils d'Ailes Isoléss ou d'Aubes en Grilles. Mechines et Métaux Nov. 1948

(6) A. D. S. Carter: Three-dimensional-flow Theories for Axial Compressurs and Turbines Proc. Inst. Mech. Engrs. 159 (1948)

(7) A. R. Howell : The Present Basis of Axial Flow Compressor Design Part $\dot{\mathrm{I}}$ Cascade Theory and Perfermance R \& M 2095 (1942)

A.R. Howell : Fluid Dynamics of Axial Compressors Proc. Inst. Mech. Engrs. 153 (1945)

\section{航 空機用材 料 の隻步}

\section{I. 緒富}

戦後，諸外国に㸝ける航空機の発達は実に目覚しい。 この発達に寄与した材料の進齿を正確に指摘したいの であるがここれはなかなかむずかしい。材料の発展の いくつが举げて，そのうち航堂蟣に関保の深いと思 われるむのについて，その性能，用途，それにわが国
䃑宏

における需給状況を紹介し，これ以上の航空機との関 倸は㴔者の御推断にまつこととする。

第 1 表に, Ti 合金, $\mathrm{Al}$ 合金中の亜鉛ジュラル ン, 強カヒドロナリウム政物, $\mathrm{Mg}$ 合金の一部と, 戦 時中わが国で航空機に使用した材料との强度比較をす 当。

第 1 表 新旧材料の强庋比西比

\begin{tabular}{|c|c|c|c|c|c|c|c|}
\hline & 合 & 比 ${ }_{\rho}^{\text {雷 }}$ & $\begin{array}{l}\text { ヤング率 } \\
\mathrm{kg} / \mathrm{mm}^{2}\end{array}$ & $\begin{array}{c}\text { 引張强さ } \\
\sigma_{B} \mathrm{~kg} / \mathrm{mm}^{2}\end{array}$ & $\underset{\sigma_{0.2} \mathrm{~kg} / \mathrm{mm}^{2}}{\text { 力 }}$ & $\frac{\sigma_{B}}{\rho}$ & $\frac{\sigma_{0 ; 2}}{\rho}$ \\
\hline \multirow{2}{*}{$\begin{array}{l}\text { 砂 } \\
\text { 型 } \\
\text { 缽 } \\
\text { 物 }\end{array}$} & $\begin{array}{l}\mathrm{Y} \text { 合 金 } \\
\text { New Hydro. }\end{array}$ & $\begin{array}{l}2.8 \\
2.7\end{array}$ & $\begin{array}{c}7.000 \\
\prime \prime\end{array}$ & $\begin{array}{l}23 \\
36\end{array}$ & & $\begin{array}{r}8.2 \\
13.2\end{array}$ & \\
\hline & $\begin{array}{l}\text { A } 10 \mathrm{v} \\
\text { M Zr }\end{array}$ & $\begin{array}{c}1.8 \\
\prime \prime\end{array}$ & $\begin{array}{c}4.000 \\
\prime \prime\end{array}$ & $\begin{array}{l}29 \\
32\end{array}$ & $\begin{array}{l}13 \\
20\end{array}$ & $\begin{array}{l}16 \\
17.8\end{array}$ & $\begin{array}{c}7.2 \\
11\end{array}$ \\
\hline \multirow{2}{*}{$\begin{array}{c}\text { 板 } \\
\dot{ } \\
\text { 鍛 } \\
\text { 造 }\end{array}$} & $\begin{array}{l}24 \mathrm{~S} \\
56 \mathrm{~S} \\
75 \mathrm{~S}\end{array}$ & $\begin{array}{l}2.77 \\
2.64 \\
2.80\end{array}$ & $\begin{array}{c}7.000 \\
" \\
"\end{array}$ & $\begin{array}{l}48 \\
30 \\
57\end{array}$ & $\begin{array}{l}34 \\
16 \\
53\end{array}$ & $\begin{array}{r}17.3 \\
11.4 \\
-\quad 20.3\end{array}$ & $\begin{array}{c}12.3 \\
6.1 \\
19\end{array}$ \\
\hline & $\begin{array}{l}\text { A Z M } \\
\text { M Zr }\end{array}$ & $\begin{array}{r}1.8 \\
" \prime\end{array}$ & $\begin{array}{c}4.000 \\
\prime \prime\end{array}$ & $\begin{array}{l}35 \\
35\end{array}$ & $\begin{array}{l}27 \\
29\end{array}$ & $\begin{array}{c}19.4 \\
\prime \prime\end{array}$ & $\begin{array}{l}15 \\
16\end{array}$ \\
\hline \multirow{2}{*}{ 品 } & $\mathrm{Ti}$ 合金 & 4.6 & 11.000 & $50 \sim 120$ & $40 \sim 110$ & $11 \sim 26$ & $8.7 \sim 24$ \\
\hline & 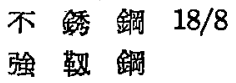 & $\begin{array}{c}7.8 \\
\prime \prime\end{array}$ & $\begin{array}{c}21.000 \\
\prime \prime\end{array}$ & $\begin{array}{c}60 \\
75 \sim 160\end{array}$ & $60 \sim 120$ & $\begin{array}{c}7.7 \\
9.6 \sim 20.5\end{array}$ & $7.7 \sim 15.4$ \\
\hline
\end{tabular}

砂型鋳物部品に対しては, $\mathrm{Al}$ 合金と $\mathrm{Mg}$ 合金であ った。 $\mathrm{Al}$ 合金には, Cu-Si-Al 采のラウタールと称 していたものか，或は $\mathrm{Cu}-\mathrm{Mg}-\mathrm{Ni}-\mathrm{Al}$ 系の $\mathrm{Y}$ 合金で ある。こ礼と比較して强力ヒドロナリウムは, 引張㤝

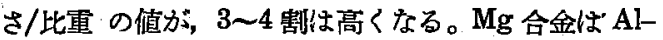
$\mathrm{Mg}$ 系，むたは $\mathrm{Al}-\mathrm{Zn}-\mathrm{Mg}$ 系のもので, 引張強さと して最大なものは， $\mathrm{Al}-\mathrm{Mg}$ 釆の A $10 \mathrm{v}$ である。こ れに比して，Zr の涯加された $\mathrm{Mg}$ 合金（仮りの記号 MZr) は，耐力/比電 の值が優れて来る。
この外，新らしい䤻物材料として，鋳鉄に $\mathrm{Mg}$ 劣少 量添加し，引張強さ $60 \mathrm{~kg} / \mathrm{mm}^{2}$ くらい，佈び $20 \%$ くらいを得たくジュラー鋳鉄があるが，これは航空猜 材料としては，余り用途务ないであうう。

践造品, 板棒類としては，超ジュラルミンといわれ 航空機の主要材料であった $24 \mathrm{~S}$ に对して，Zn を合ん ザジュラルミン 75S が多く便われて来たようである。 $75 \mathrm{~S}$ は米国に於ける慗造会㖣の商品名であるが, この 系の Al 合金は，世界に先えじて日本の航空界に探用 